\title{
Ciliary bands in the prostomium region of Dimorphilus gyrociliatus (Annelida: Dinophiliformia) and their involvement in food uptake
}

\author{
E.G. Fofanova ${ }^{1^{*}}$, E.E. Voronezhskaya ${ }^{2}$ \\ Koltzov Institute of Developmental Biology, Russian Academy of Sciences, Vavilova ave, 26, \\ Moscow, 119334 Moscow, Russia. \\ ${ }^{1}$ ORCID 0000-0001-9577-7514, ${ }^{2}$ ORCID 0000-0002-9953-2538 \\ * Corresponding author. E-mail: fofanova@idbras.ru
}

\begin{abstract}
A prototroch is a characteristic larval idiosyncratic structure conserved among Lophotrochozoa. It appears as the first prominent structure during embryogenesis, serves for swimming and filter-feeding, then degenerates or is modified after metamorphosis. Using cutting-edge confocal laser scanning microscopy, we investigated the detailed structure of the Dimorphilus gyrociliatus prototroch area and demonstrated that it is much more complex than previously thought. The first row of ciliated cells differentiates at the trochophore stage. By juvenile stage, three rows of ciliated cells are located in the prostomium region: an anterior row of cells with long $(14-16 \mu \mathrm{m})$ cilia, an intermediate row of cells with short (3-4 $\mu \mathrm{m})$ cilia, and a posterior row of cells with cilia of middle length (9$10 \mu \mathrm{m})$. Each ciliated row consists of two bands of cilia-bearing cells. We suggest that the anterior row represents what is commonly considered a prototroch. At the same time, the intermediate row is considered homologous to the adoral ciliary zone, and the posterior row is considered homologous to the metatroch. Older individuals retain this ciliated apparatus until the last days of their life. With age, cilia in prototroch and metatroch become twice shorter; and the prototroch gets wider, at the end consisting of four lines of ciliated cells. Interestingly, under the inhibition of muscle contraction, the freshly hatched juveniles maintain the ability to uptake food particles. These findings confirm earlier observations showing that $D$. gyrociliatus uses its complex ciliated apparatus in the prostomial region for filter-feeding in addition to bulbus-scrabbing. Thus, we clarified the organization of the ciliary bands of $D$. gyrociliatus located in the prostomial region, documented their persistence during ontogenesis, as well as confirmed the participation of the ciliary apparatus in active food intake. These data support the paedomorphic character demonstrated for Dimorphilus gyrociliatus.

How to site this article: Fofanova E.G., Voronezhskaya E.E. 2021. Ciliary bands in the prostomium region of Dimorphilus gyrociliatus (Annelida: Dinophiliformia) and their involvement in food uptake // Invert. Zool. Vol.18. No.3. P.223-239. doi: 10.15298/ invertzool.18.3.03
\end{abstract}

KEY WORDS: prototroch, adoral ciliary field, metatroch, dinophilidae, paedomorphosis, Lophotrochozoa, ciliary bands, filter-feeding.

The paper is devoted to 70th anniversary of Prof. V.V. Malakhov.

Статья посвящена 70-летию со дня рождения проф., акад. В.В. Малахова. 


\title{
Ресничные тяжи простомиума у Dimorphilus gyrociliatus (Annelida: Dinophiliformia) и их роль в захвате пищевых частиц
}

\author{
Е.Г. Фофанова ${ }^{1 *}$, Е.Е. Воронежская² \\ ФГБУН Институт биологии развития им. Н.К. Кольцова, РАН, Вавилова, 26, 119334, \\ Москва, Россия. \\ ${ }^{1}$ ORCID 0000-0001-9577-7514, ${ }^{2}$ ORCID 0000-0002-9953-2538 \\ * Автор для переписки. E-mail: fofanova@idbras.ru
}

РЕЗЮМЕ: Прототрох — характерная личиночная структура, консервативная в ряду трохофорных животных. Прототрох появляется как первая заметная ресничная структура в эмбриогенезе, используется личинкой для локомоции и питания, а затем дегенерирует или модифицируется в процессе метаморфоза. Используя современную конфокальную микроскопию, мы детально описали область прототроха у Dimorphilus gyrociliatus от момента возникновения до последних дней существования особи, и показали, что она устроена значительно сложнее, чем считалось ранее. Первый ряд ресничных клеток появляется в развитии на стадии трохофоры. К стадии вылупления в районе простомиума обнаруживаются три ресничных тяжа: передний, с длинными ресничками $(14-16 \mu \mathrm{m})$; средний, с короткими ресничками $(3-4 \mu \mathrm{m})$; и задний с ресничками средней длины $(9-10 \mu \mathrm{m})$. Каждый тяж состоит из двух рядов клеток, несущих реснички. Мы полагаем, что верхние ряды ресничек представляют собой то, что в литературе рассматривается как собственно прототрох, в то время как срединный желобок с короткими ресничками гомологичен адоральной ресничной зоне, а нижний ряд ресничных клеток гомологичен метатроху. Ресничный аппарат сохраняется в процессе онтогенеза и обнаруживается у возрастных особей в самом конце жизни. С возрастом реснички в прототрохе и метатрохе становятся в два раза короче, однако прототрох включает уже четыре ряда ресничных клеток. Интересно отметить, что после ингибирования мышечной активности глоточного бульбуса вылупившиеся ювенили сохраняют способность захватывать пищевые частицы. Этот эксперимент подтверждает ранее высказанную гипотезу об использовании ресничного аппарата области простомиума взрослыми диморфилюсами для фильтрации, в дополнение к скребущей мышечной активности бульбуса. Таким образом, мы уточнили организацию цилиарных тяжей $D$. gyrociliatus, расположенных в простомиальной области, продемонстрировали их сохранение в процессе онтогенеза, а также подтвердили участие цилиарного аппарата в активном захвате пищевых частиц. Полученные результаты являются дополнительным подтверждением черт педоморфоза, отмеченным ранее для Dimorphilus gyrociliatus.

Как цитировать эту статью: Fofanova E.G., Voronezhskaya E.E. 2021. Ciliary bands in the prostomium region of Dimorphilus gyrociliatus (Annelida: Dinophiliformia) and their involvement in food uptake // Invert. Zool. Vol.18. No.3. P.223-239. doi: 10.15298/ invertzool.18.3.03

КЛЮЧЕВЫЕ СЛОВА: прототрох, адоральная ресничная зона, метатрох, динофилиды, педоморфоз, Lophotrochozoa, ресничные тяжи, питание путем фильтрации. 


\section{Introduction}

Dimorphilus gyrociliatus is a marine interstitial annelid with a unique morphology resembling other Lophotrochozoa groups. Based on early descriptions, adults can be easily confused with Nemertea (Jones, Ferguson, 1957), Platyhelminthes (Schmidt, 1857), or Rotifera (Graff, 1882; Lang, 1884; Schimkewitsch, 1895). Thus, the systematic position of Dimorphilus shifted from Platyhelminthes and Rotifera to Annelida, where it is now placed molecularly as a sister group to Errantia and Sedentaria, always depending on the specific morphological characteristics that attracted researchers' attention (Schmidt, 1857; Nelson, 1904, 1907; Shearer, 1911; Jones, Ferguson, 1957; Hermans, 1969; Windoffer, Westheide, 1988b; Müller, 2006; Fofanova et al., 2014; Kerbl et al., 2017; Martín-Durán et al., 2021). Adult representatives of Dinophiliformia demonstrate several structures otherwise mainly found in annelid larvae: the compact brain, protonephridia, and absence of setae. Also, there was no clear understanding of the feeding strategy of this species.

During the first morphological description, Schmidt suggested that the Dimorphilus use their ciliary apparatus located around the mouth for filter feeding, similar to trochophore larvae (Schmidt, 1857). Later, Jennings suggested that Dimorphilus utilizes two types of food particle uptake: scrabbing with a muscular bulbus and filtering using cilia (Jennings, Gelder, 1969). His suggestion was based on the detailed maps of water flows around the adult worm's head. However, at that time, visualization techniques did not allow for a close-up investigation of ciliary structures of such tiny organisms as $D i$ morphilus while alive and especially while moving. Thus, until now, the exact feeding strategy and underlying ciliary structures of $D$. gyrociliatus were poorly understood. Meanwhile, this feature is crucial to characterize potentially paedomorphic traits of adult $D . g y$ rociliatus.

The filter-feeding mechanism is well-studied for many representatives of Lophotrochozoa (Lacalli, 1986, 1988; Riisgård, Larsen, 2001;
Henry et al., 2007; Amiel et al., 2013; Marinkovic et al., 2020) and is used for the reconstruction of phylogeny and evolution of ciliary bands in various trochophore larvae (Rouse, 2000; Nielsen 2004, 2009). In this line of investigation, the ciliary apparatus of adult Dimorphilus is mentioned as ciliary bands in the prostomial region which are not closed on the dorsal side (Fofanova et al., 2014; Kerbl et al., 2017; Jimi et al., 2020), and the prototroch of egg-envelope-encased embryos/early larvae represents a solitary broad band of cells bearing long cilia (Fofanova et al., 2014; Kerbl et al., 2017; Jimi et al., 2020). In recent studies providing illustrations of ciliary structures, the prototroch is designated as the second ciliary band named «cb2» in later stages (Kerbl et al., 2016), whereby scanning electron microscopy reveals it as a massive bundle of cilia, whose detailed organization is unclear (Kerbl et al., 2017; Jimi et al., 2020).

In the present paper, we describe the prostomial ciliation from the trochophore stage through adulthood in details. We demonstrate that the fully developed filtering apparatus consists of three separated bands containing long cilia, cilia of medium length, and short cilia, respectively. Anterior (prototroch) and posterior (metatroch) ciliary bands surround the intermediate feeding groove (adoral ciliary zone). Altogether, this ciliary structure is used in addition to bulbus-scrabbing for food uptake. Our results provide a morphological base and experimental evidence proving the early hypothesis of Schmidt and Jennings about Dimorphilus filterfeeding. We also argue that the retention of this ciliary apparatus into older stages is another paedomorphic characteristic of D. gyrociliatus.

\section{Material and methods}

\section{Dimorphilus gyrociliatus laboratory cul- ture}

The Dimorphilus gyrociliatus culture was obtained from the Mediterranean Sea, Napoli Zoological station (Italy). Stock animals were reared in small plastic tanks with artificial seawater (33\% salinity) at $21-22{ }^{\circ} \mathrm{C}$ without aera- 
tion and fed with homogenized frozen nettle (Urtica sp.) leaves once a week. Water was changed once a week before each feeding cycle.

Selection of embryonic, juvenile, adult, and elder stages

Dimorphilus gyrociliatus cocoons contained 1-9 large (female) embryos and 1-3 small (dwarf males) embryos (Shearer, 1911; Mauri et al., 2002). Dwarf males die soon after hatching, and also lack both continuous ciliary bands as well as a digestive system (Windoffer, Westheide, 1988a, b). Therefore, only females represent the adult population, and that is why we focused only on females of $D$. gyrociliatus for this study, which were collected and studied at various ontogenetic stages. We monitored the culture daily to define the trochophore (1.5 days after oviposition, d.p.o.), juvenile (5 d.p.o.), adult (20-30 d.p.o.), and senior (75 d.p.o.) stages for further morphological analysis of the prostomial region (Fig. 1A). To obtain certain developmental stages, we collected egg cocoons just after their appearance and monitored them daily. Every other day, the worms were transferred to new Petri dishes and fed with frozen Urtica. This approach allowed us to stage each worm in detail. For morphological examination, we collected specimens at the trochophore (1.5-4 d.p.o.), juvenile (5-7 d.p.o.), adult (14-30 d.p.o.), and senior (71-80 d.p.o.) stages. In our conditions, by the 75 th day of development, half of the animals of this generation die, therefore we consider this point for the remaining animals to be the onset of old age (senior). Such animals usually die within the next 3-5 days, which is why we consider this stage to be the last days of the life of individuals. Thus, we followed the whole range of $D$. gyrociliatus developmental stages.

\section{Fluorescence staining of ciliary structures, muscles, cell borders, and nuclei \\ Dimorphilus gyrociliatus individuals at se-} lected stages were subjected to whole-mount immunocytochemical and histochemical staining. An antibody against acetylated alpha-tubulin was used to label individual cilia and their compactization into ciliary bands. Alexa 488conjugated phalloidin allowed visualization of cell borders and muscle fibers. The specimens were fixed with $4 \%$ paraformaldehyde (PFA) in phosphate-buffered saline (PBS, $0.01 \mathrm{M}$, $\mathrm{pH}=7.4$ ) at $4{ }^{\circ} \mathrm{C}$ overnight. Immunostaining was then conducted according to a protocol established for juveniles and adults of $D$. gyrociliatus (Fofanova, Voronezhskaya, 2012; Fofanova et al., 2014). We used anti-acetylated $\alpha$-tubulin antibody diluted 1:5000-1:10000 (Sigma-Aldrich, USA; T-6793; monoclonal: clone 6-11B1 , ascites fluid) in PBS containing $0.1 \%$ Triton X-100 (PBS-TX). The primary antibody was then visualized with the secondary goat antimouse antibody conjugated with Alexa-633 (1:1000; Molecular Probes, USA, A-21050; polyclonal). Phalloidin-Alexa 488 was added with a secondary antibody (1:1000, ThermoFisher, A 12379). Cell nuclei were stained with Hoechst-33342 (Sigma, H 1399) $(0.1 \mu \mathrm{g} / \mathrm{ml})$. After 3x10 min washing in PBS, the specimens were mounted on glass slides in $70 \%$ glycerol.

A Zeiss LSM 880 confocal laser scanning microscope was used for the detailed analysis of the specimens. Stacks of optical sections taken with $63 \mathrm{x}$ objective at $0.27 \mathrm{~m}$ intervals were processed by Image J (Abramoff et al., 2004) to

Рис. 1. Стадии развития и организация простомиума Dimorphilus gyrociliatus. A - шкала стадий развития в днях после откладки кокона; d.p.o. - дни после откладки кокона; B-D — ресничная организациия простомиума, согласно нашим раннее полученным результатам, вид с вентральной стороны (В), вид с дорсальной стороны (C); прототрох, вид с вентральной стороны крупным планом (D); E-F - уточненное детализированное представление об организации простомиума, вид с вентральной стороны (E), вид с дорсальной стороны (F), прототрох и метатрох, вид с вентральной стороны крупным планом (G).

Красный — тубулин. Обозначения act - акротрох; acz — переднее ресничное поле; cb3 — ресничный шнур туловищного отдела; gr — желобок; то — рот; $\mathrm{mt}$ - метатрох; nu — нухальный орган; pt — прототрох. Масштабы: B, C, E, F - 25 мкм; D, G - 10 мкм. 


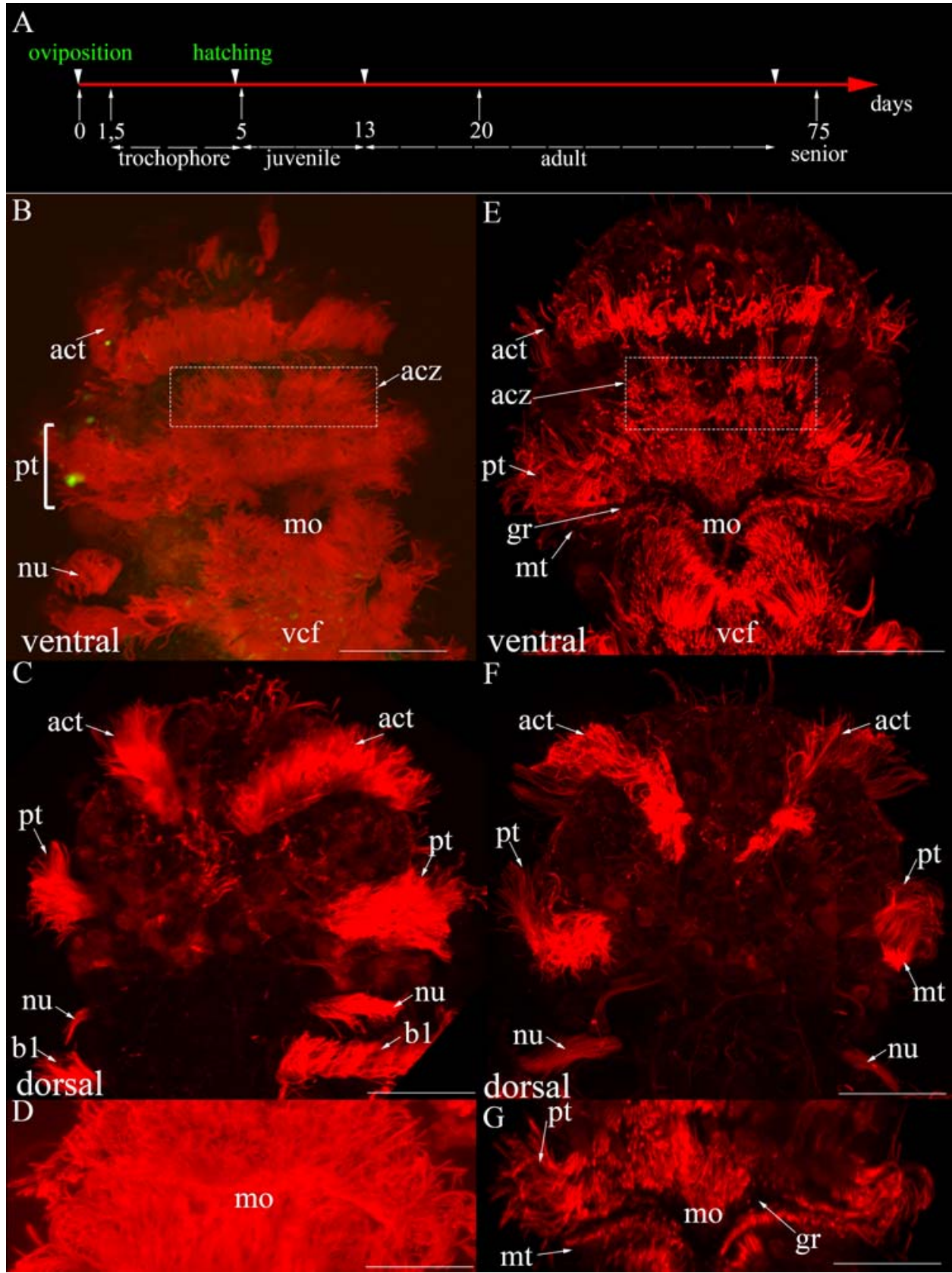

Fig. 1. Dimorphilus gyrociliatus staging and prostomial region organization according previous studies and our recent results . A - staging scale according to the time after oviposition, d.p.o. - days after oviposition; B-D - prostomial region, according to our previous results, ventral view (B), dorsal view (C), prototroch, higher magnification, ventral view (D); E-F - new, improved data of the prostomial region ciliary structures organization. The same areas as in B-D are shown: ventral view (E), dorsal view (F); prototroch, higher magnification, ventral view $(\mathrm{G})$.

Red — tubulin. Abbreviations: act — acrotroch; acz — anterior ciliary zone; cb3 — ciliary band 3; gr — groove; mo mouth; $\mathrm{mt}$ - metatroch; $\mathrm{pt}$ - prototroch; nu — nuchal organ; vcf — ventral ciliary field. Scale bars: B, C, E, F - 25 $\mu \mathrm{m} ; \mathrm{D}, \mathrm{G}-10 \mu \mathrm{m}$. 
obtain two-dimensional images. Maximum intensity projections of an optimal number of individual sections per stack were selected to demonstrate the structures of interest.

\section{Filter-feeding experiments}

We collected egg cocoons just after egglaying, placed them into a $5 \mathrm{ml}$ Petri dish, and cultured them for five days at $21-22{ }^{\circ} \mathrm{C}$ until hatching. Newly hatched juveniles (5 d.p.o., before the first food uptake) were separated into one control and two experimental groups. The control group was fixed with $4 \%$ PFA just after hatching before they were able to uptake any food. In the first experimental group, muscular contractions were blocked with $0.125 \mathrm{M}$ $\mathrm{MgCl}_{2}$. The second experimental group was maintained in filtered seawater. Both experimental groups were simultaneously fed with Urtica. Control and two experimental groups were examined under a dissecting microscope during the food uptake analysis. No bulbus movements were documented in the group after muscle relaxation, while bulbus movements were clearly seen in two other groups. After four hours of feeding, the first and second experimental groups were fixed with 4\% PFA. Representatives of control and two experimental groups were examined for the presence/absence of food particles in the intestine under the Zeiss LSM 880 confocal microscope. We used a control group to visualize empty stomachs, in two experimental groups we demonstrate that ciliary and ciliary combined with scrabbing feeding modes are possible. We used frozen homogenized Urtica leaves as food. To detect food presence we used 488 laser to induce chlorophyll fluorescence.

\section{Results}

Ciliary structures in the prostomial region of $D$. gyrociliatus juveniles

Earlier it was demonstrated that the prostomial region of juvenile Dimorphilus contains two ciliary bands, known as prototroch and acrotroch. These two ciliary bands are located anterior to the mouth opening (Fig. 1B). The longitudinal ventral ciliary field and several transverse ciliary bands are located posterior to the mouth along the body. The prototroch has a gap on the dorsal side (Fig. 1C, F) and an anterior extension anterior to the mouth on the ventral side (Fig. 1B). The mouth opening is often hidden by the long cilia of the prototroch and ventral field, which look very bright after immunostaining against tubulin. Thus, these ciliated structures appear merged, giving the impression of one single massive ciliary band (Fig. 1D).

We were able to determine additional ciliary bands and separate rows of multiciliated cells at the ventral prostomial region in our preparations. The single-band-looking prototroch consists of two rows of long cilia separated by a groove (with the cells forming the groove bearing short cilia, see description below) (Fig. 1E, G). Below we describe the details of the prostomial region at subsequent developmental stages.

\section{Ontogeny of prostomial region}

The first row of cilia-bearing cells appears laterally on the left and right sides of the blastopore during trochophore stage (Fig. 2A). Phalloidin staining combined with nuclear labeling reveals that this row consists of two lines of ciliated cells (Fig. 2B-D).

Upon reaching juvenile stage, three rows of ciliated cells are located in the prostomial region: an anterior row of cells with long (14-16 $\mu \mathrm{m})$ cilia, an intermediate row of cells with short (3-4 $\mu \mathrm{m})$ cilia, and a posterior row of cells with cilia of middle length (9-10 $\mu \mathrm{m}$, Fig. 3A-D). A nuchal organ is located posteriorly to all prostomial structures (Fig. 3A-D). Phalloidin staining reveals two lines of ciliated cells in each row (Fig. 3A-D). The cells with short cilia organize a $6 \mu \mathrm{m}$-wide groove surrounded by anterior and posterior rows with long cilia. Each cell from the anterior row bears about $5015 \mu \mathrm{m}$-long cilia (Fig. 3A, B), while the posterior row of cells bears about 40 cilia, which are $8-10 \mu \mathrm{m}$ long (Fig. 3C, D).

The prostomial ciliary organization during the adult stage is quite similar to the juvenile 


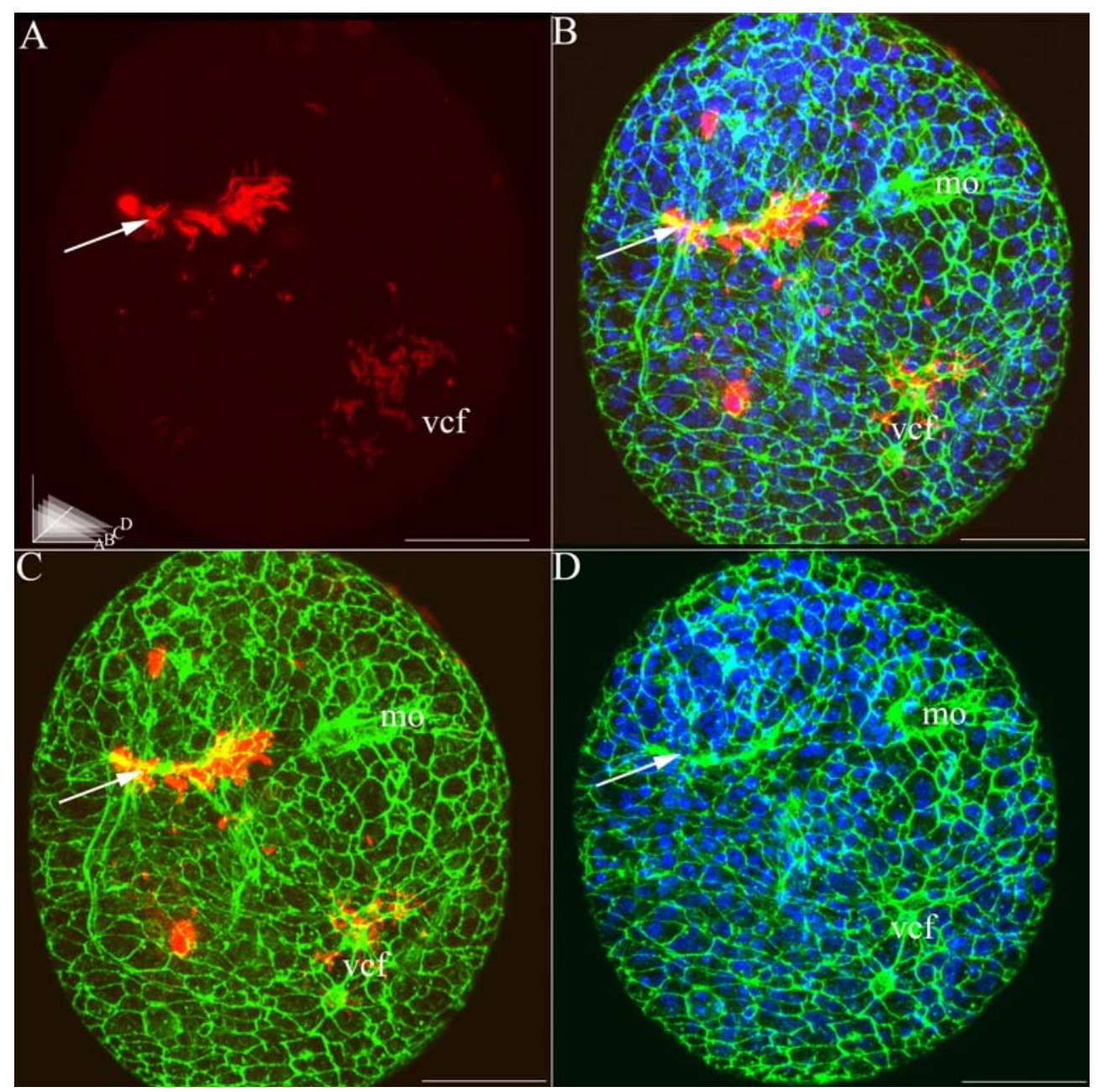

Fig. 2. Trochophores Dimorphilus gyrociliatus (2 days after oviposition) with the first ciliary structures in the prostomial region ( 2 days after oviposition). A - the row of ciliated cells laterally to the mouth and ciliary field in the developing ventral ciliary field; B - the general view of the trochophore with marked cilia, cell borders and nuclei; $\mathrm{C}$ - the general view of the trochophore with marked cilia and cell borders; D - the general view of the trochophore with marked cell borders and nuclei. The condensed actin filaments are visible underneath the row of ciliated cells and ventral ciliary field as well as in the region of the developing mouth.

Red - tubulin, green — actin, blue - hoechst staining cell nuclei. Abbreviations: arrow — cilia, mo - mouth, vcf ventral ciliary field, arrow - the concentration of actin filaments. Scale bar $20 \mu \mathrm{m}$.

Рис. 2. Трохофоры Dimorphilus gyrociliatus (2 дня после откладки кокона) с первыми ресничными структурами в области простомиума. А - ряд ресничных клеток латерально от ротового отверстия и ресничное поле развивающейся вентральной ресничной полоски; В - общий план трохофоры с маркированными ресничными структурами, клеточными границами и ядрами; $\mathrm{C}$ - общий план трохофоры с маркированными ресничными структурами и клеточными границами; D - общий план трохофоры с маркированными клеточными границами и ядрами. Концентрация актиновых филаментов наблюдается под рядом ресничных клеток, вентральной ресничной полоской и в области формирующегося рта.

Красный — тубулин, зеленый — актин, синий — ядра. Обозначения: стрелка — группа ресничных клеток; то рот; vcf - вентральная ресничная полоска. Масштаб 20 мкм. 


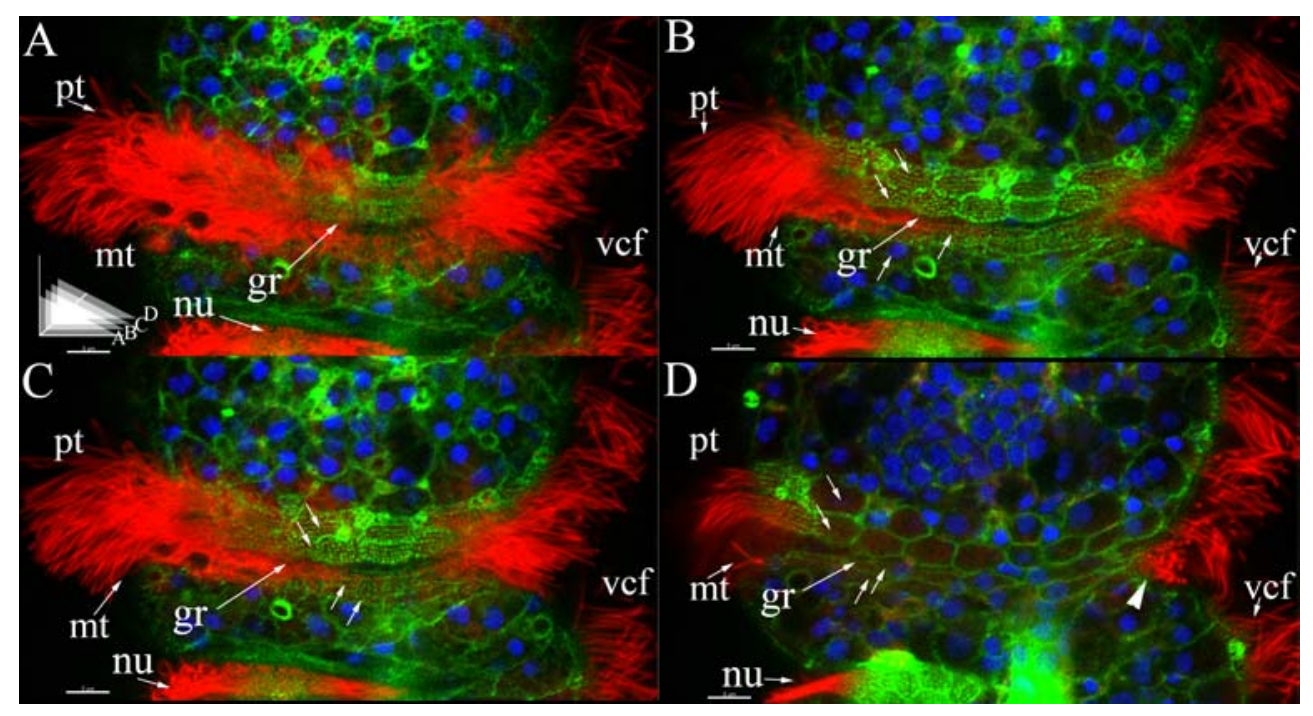

Fig. 3. A juvenile stage of Dimorphilus gyrociliatus before hatching (5 days after oviposition), lateral view. Four subsequent optical sections. A - surface view with anterior and posterior rows of cells with long cilia and cilia of medium length, respectively; B - deeper view demonstrating cell structure of all three ciliary rows, each row consists of two lines of cells. Ciliary basements are labeled with phalloidin. The groove and metatroch cilia are visible; $\mathrm{C}$ - deeper view demonstrating cell structure of prototroch and metatroch rows of cells, each row consists of two lines of cells; D - deeper view, prototroch, metatroch, groove cells, and short cilia (arrowhead) are visible. The cilia of intermediate groove cells (arrow) are shorter than surrounding prototroch and metatroch cilia. A nuchal organ located posteriorly to all prostomial structures.

Red — cilia, green — actin, blue — nuclei. Abbreviations: gr — groove; mo — mouth; $\mathrm{mt}$ - metatroch; nu — nuchal organ; $\mathrm{pt}$ - prototroch; double arrows mark the two lines of cells anteriorly to the groove and two lines of cells posteriorly to the groove. Scale bar $5 \mu \mathrm{m}$.

Рис. 3. Ювенильная особь Dimorphilus gyrociliatus, непосредственно перед вылуплением, вид сбоку (5 дней после откладки кокона). Четыре последовательных оптических среза. А - вид поверхности с передним и задним рядами клеток, несущими длинные и реснички средней длины; В - более глубокий срез, демонстрирующий клеточную структуру всех трех ресничных шнуров, каждый состоит из двух рядов клеток. Основания ресничек мечены фаллоидином. Виден желобок и реснички метатроха; C - более глубокий срез, демонстрирующий клеточную структуру прототроха и метатроха, каждый состоит из двух рядов клеток. Основания ресничек промаркированы фаллоидином; $\mathrm{D}$ - более глубокий срез, видны клетки прототроха, метатроха и желобка.

Красный — тубулин, зеленый — актин, синий — ядра. Обозначения: gr — пищевой желобок; mo — poт; $\mathrm{mt}-$ метатрох; nu - нухальный орган; $\mathrm{pt}$ - прототрох; два ряда клеток перед желобком и два ряда клеток после желобка отмечены двойными стрелками. Масштаб 5 мкм.

stage. Three ciliary bands surrounding the $\mathrm{Y}$ shaped mouth are found (Fig. 4A-D) in a similar organization as described above for the juvenile stage (Figs 5B, C; 7B, C). The short cilia of the intermediate row are located within the groove and are difficult to visualize because they are hidden by long cilia of prototroch and metatroch. However, they can be detected on certain optical sections from the ventral side (Fig. 5A), and are separated from long prototroch and metatroch cilia in the lateral side view (Fig. 5B, C). During all the examined adult stages (14-30 d.p.o.), the ciliary structures in the prostomial region maintain the organization described above.

The prostomial ciliary organization during senior/senescent stage is mostly the same as at adult stages: anterior rows with long cilia, the groove with short cilia, and posterior row with middle cilia (Fig. 6A-E). However, cilia of the 


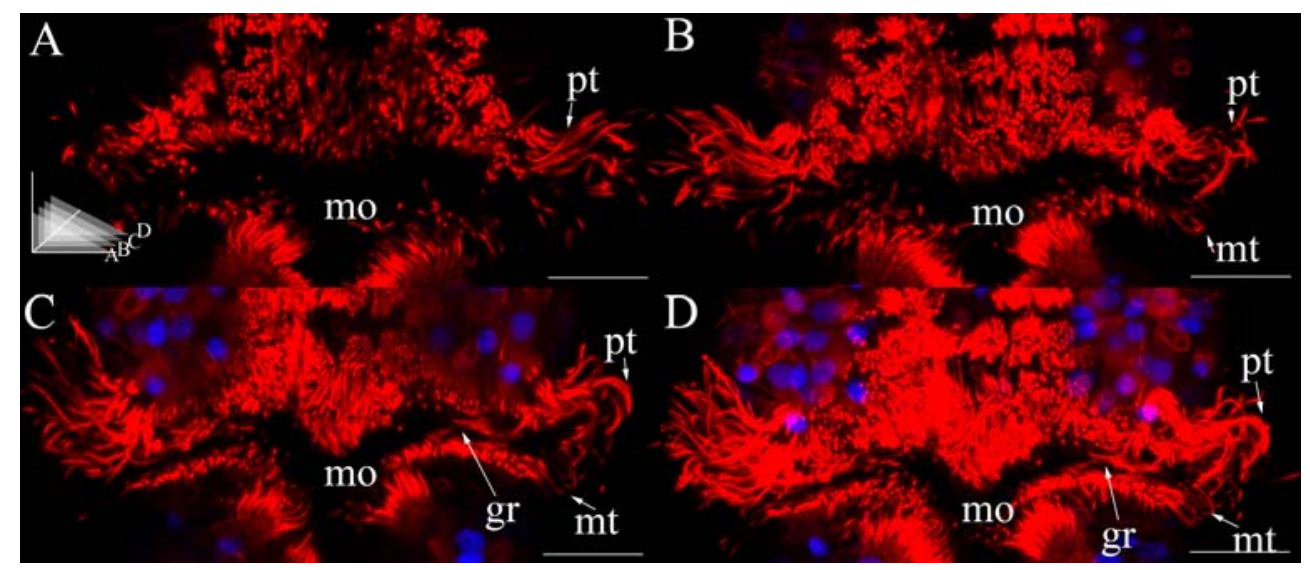

Fig. 4. The juvenile stage of Dimorphilus gyrociliatus after hatching (5 days after oviposition), ventral view. Four subsequent optical sections of the ventral surface. A - a surface section demonstrates the prototroch cilia; B - a deeper section demonstrating prototroch and metatroch cilia; $\mathrm{C}$ - a deeper section demonstrating prototroch, metatroch and groove between them; $\mathrm{D}$ - a deeper section demonstrating prototroch, metatroch and groove between them, some cilia are visible in the groove.

Red - cilia, blue - nuclei. Abbreviations: gr — groove; $\mathrm{mt}$ - metatroch; mo - mouth; pt — prototroch. Scale bar: $20 \mu \mathrm{m}$.

Рис. 4. Ювенильная особь Dimorphilus gyrociliatus после вылупления (5 дней после откладки кокона), вид с вентральной стороны. Четыре последовательных оптических среза, вид с вентральной стороны. A - поверхностный срез на уровне ресничек прототроха; В - более глубокий срез, демонстрирующий реснички прототроа и метатроха; $\mathrm{C}$ - более глубокий срез, демонстрирующий реснички прототроха, метатроха и желобок между ними; D - более глубокий срез, демонстрирующий реснички прототроха, метатроха и желобок между ними, в желобке видны реснички.

Красный — тубулин, синий — ядра. Обозначения: gr — желобок; mo — ротовое отверстие; $\mathrm{mt}$ - метатрох; $\mathrm{pt}$ протротрох. Масштаб 20 мкм.

anterior and posterior rows get shorter, while the groove becomes wider $(10 \mu \mathrm{m})$. Additionally, two more lines of ciliated cells are visible in the anterior row to the contrary of previous stages (Figs 6E, F; 7A-D).

\section{Feeding experiment}

As expected, the control group showed an empty intestine (Fig. 8A). The experimental group with relaxed muscles and exposed to the food had take up food particles, which showed in their stomach and intestine (Fig. 8B), similarly to the second control group exposed to the food without muscular relaxation (Fig. 8C). This experiment demonstrated the ability of Dimorphilus to uptake food particles even in the case of relaxed muscular bulbus. We suggest that coordinated activity of ciliary bands around the mouth underlies this possibility and ensures food uptake in our experimental condition.

\section{Discussion}

The previous and recent description of the prostomial region morphology

Taken together, we suggest that the anterior row represents what is commonly considered the prototroch. At the same time, the intermediate row (groove) represents the adoral ciliary zone, and the posterior row represents the metatroch.

Using immunochemistry and confocal laser scanning microscopy, we have shown that the ciliary apparatus on the ventral side of female $D$. gyrociliatus resembles the general structure, arrangement, and functionality of prototroch and metatroch in typical trochophore larva as 


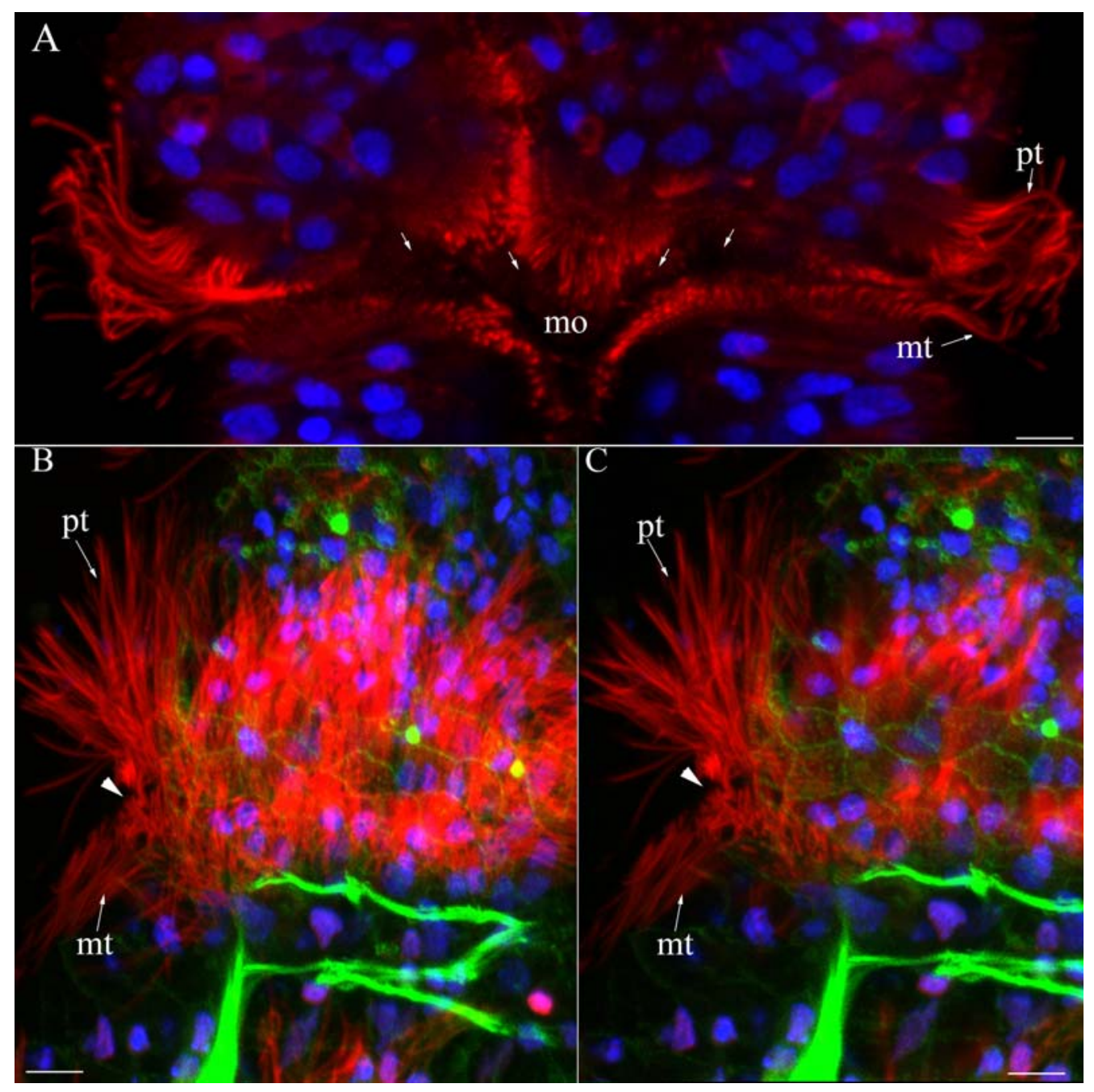

Fig. 5. The adult of Dimorphilus gyrociliatus (25 days after oviposition), ventral and lateral views. A - a ventral side section, demonstrating the ciliated groove (marked by four arrows); B - adult individual, surface view, demonstrating the long and cilia of medium length of prototroch and metatroch, respectively, and short cilia between them (arrowhead); $\mathrm{C}$ - adult individual, a surface optical section demonstrating the long and cilia of medium length of prototroch and metatroch, respectively, and short cilia between them (arrowhead).

Red - tubulin, green - actin, blue - nuclei. Abbreviations: gr — groove; $\mathrm{pt}$ - prototroch; mo - mouth; $\mathrm{mt}-$ metatroch, arrows indicate short cilia zone. Scale bars: A $-15 \mu \mathrm{m}$; B, C $-10 \mu \mathrm{m}$.

Рис. 5. Взрослая особь Dimorphilus gyrociliatus (25 дней после откладки кокона), вид с вентральной и латеральной сторон. А - оптический срез с вентральной стороны, демонстрирующий ресничный желобок (промаркирован четырьмя стрелками); В - взрослая особь, вид с вентральной стороны, демонстрирующий длинные и реснички средней длины прототроха и метатроха, соответственно, и короткие реснички между ними (треугольник); С — взрослая особь, более глубокий оптический срез, демонстрирующий длинные реснички прототроха. реснички средней длины метатроха и короткие реснички между ними (треугольник).

Красный — тубулин, зеленый — актин, синий - ядра. Обозначения: gr - желобок; mo - poт; mt - метатрох; pt - протрох. Масштабы: А - 15 мкм; В, C - 10 мкм. 


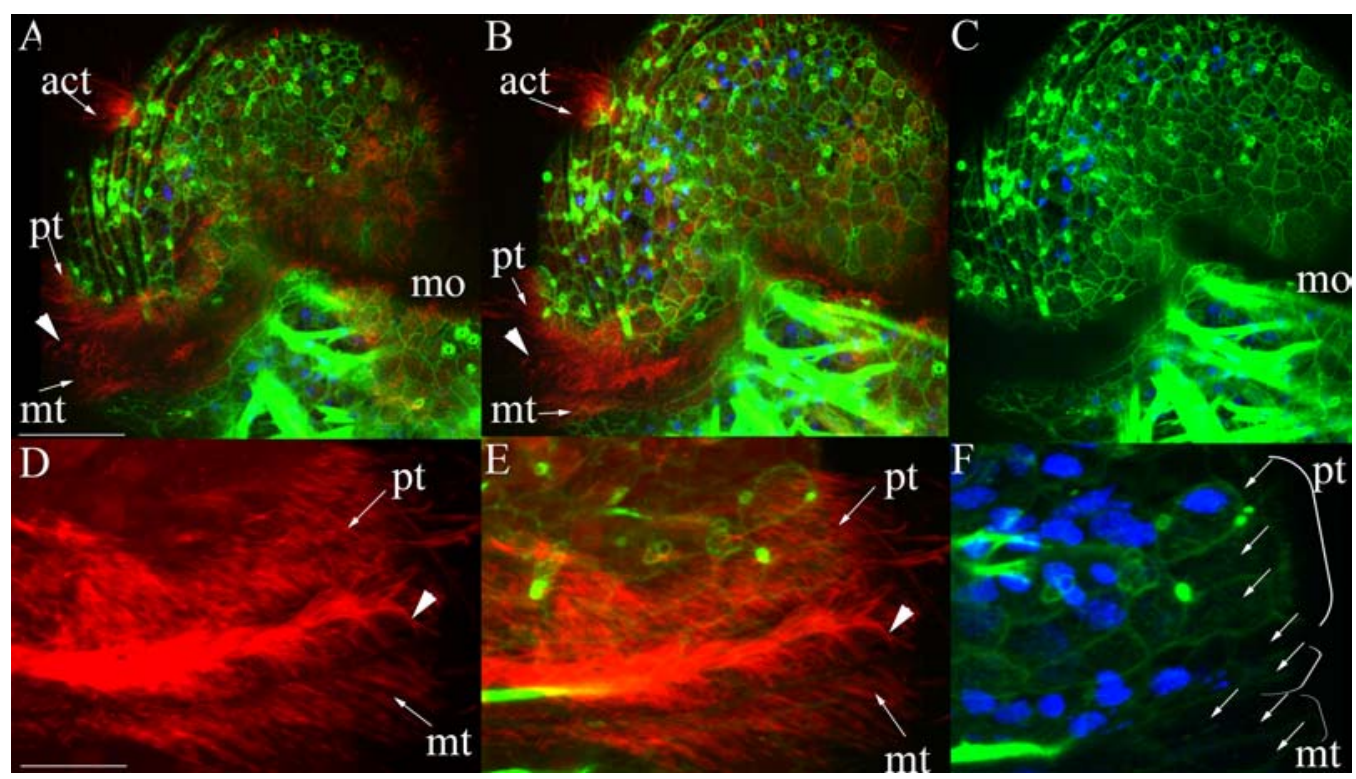

Fig. 6. The senior stage (75 days after oviposition) of Dimorphilus gyrociliatus, ventral view. A-C - a general view on prostomium region ciliated structures. A, B - various optical sections are demonstrating details of groove, prototroch, and metatroch cells; $\mathrm{C}$ - cell borders between prostomial ciliary cells; D-F higher magnification of ciliary rows in the prostomial region: cilia (D), cilia and cell borders (E), cell borders and nuclei (F). Note the shortening of prototroch and metatroch cilia. (F).

Red - tubulin, green - actin, blue - nuclei. Abbreviations: act - acrotroch; gr — groove; mo - mouth; $\mathrm{mt}$ metatroch; $\mathrm{pt}$ - prototroch. In A, B, D, E, arrowhead indicates short cilia zone; in F each arrow indicates a line of multiciliated cells. Scale bars: A-C $-50 \mu \mathrm{m} ; \mathrm{D}-\mathrm{F}-30 \mu \mathrm{m}$.

Рис. 6. Возрастная особь Dimorphilus gyrociliatus (75 дней после откладки кокона), вид с вентральной стороны. А-C - общий вид ресничных структур в области простомиума. А, В - разные оптические срезы, демонстрирующие детали клеток желобка, прототроха и метатроха; C - границы между ресничными клетками простомиума; D-F - увеличенное изображение ресничных рядов простомиума: реснички (D), реснички и границы клеток (E), границы клеток и ядра (F).

Красный — тубулин, зеленый — актин, синий — ядра. Обозначения: act — акротрох; gr — желобок; то — poт; $\mathrm{mt}$ - метатрох; pt — прототрох. На A, B, D, Е треугольник указывает на короткие реснички, на F каждая стрелка указывает на один ряд мультицилиарных клеток. Масштабы: A-C $-50 \mu \mathrm{m} ; \mathrm{D}-\mathrm{F}-30 \mu \mathrm{m}$.

described by Nielsen (Lacalli, 1986; Nielsen, 2004) more closely than after previous descriptions (Fig. 9).

According to Nielsen's definition, a trochophore is a «planktotrophic protostome larva with prototroch and sometimes a metatroch with multiciliated cells, surrounding the adoral ciliary zone; gastrotroch (= neurotroch) and telotroch may be present". This definition is similar to Hatschek's definition: larva with an apical organ, pre-oral and post-oral ciliary bands flanking a food groove, a gut, and a pair of protonephridia (Hatschek, 1878). Kleinenberg introduced the term prototroch as a ring of cilia derived from specific cells — trochoblasts (Kleinenberg, 1886). A prototroch seems to be a highly conserved structure that is present in Annelida, Mollusca, Entoprocta, Ectoprocta, Nemertea, and Rotifera (Ivanova-Kazas, 1995; Rouse, 1999, 2000; Nielsen, 2004; Marinković et al., 2020; Wu et al., 2020).

Lacalli provided an accurate and detailed study of the prototroch structure on Phyllodoce larvae. Using electron microscopy, the author showed four rows of multiciliated cells in the prototroch of the Phyllodoce trochophore (Lacalli, 1986). According to that description, the second row contains the most prominent cilia 


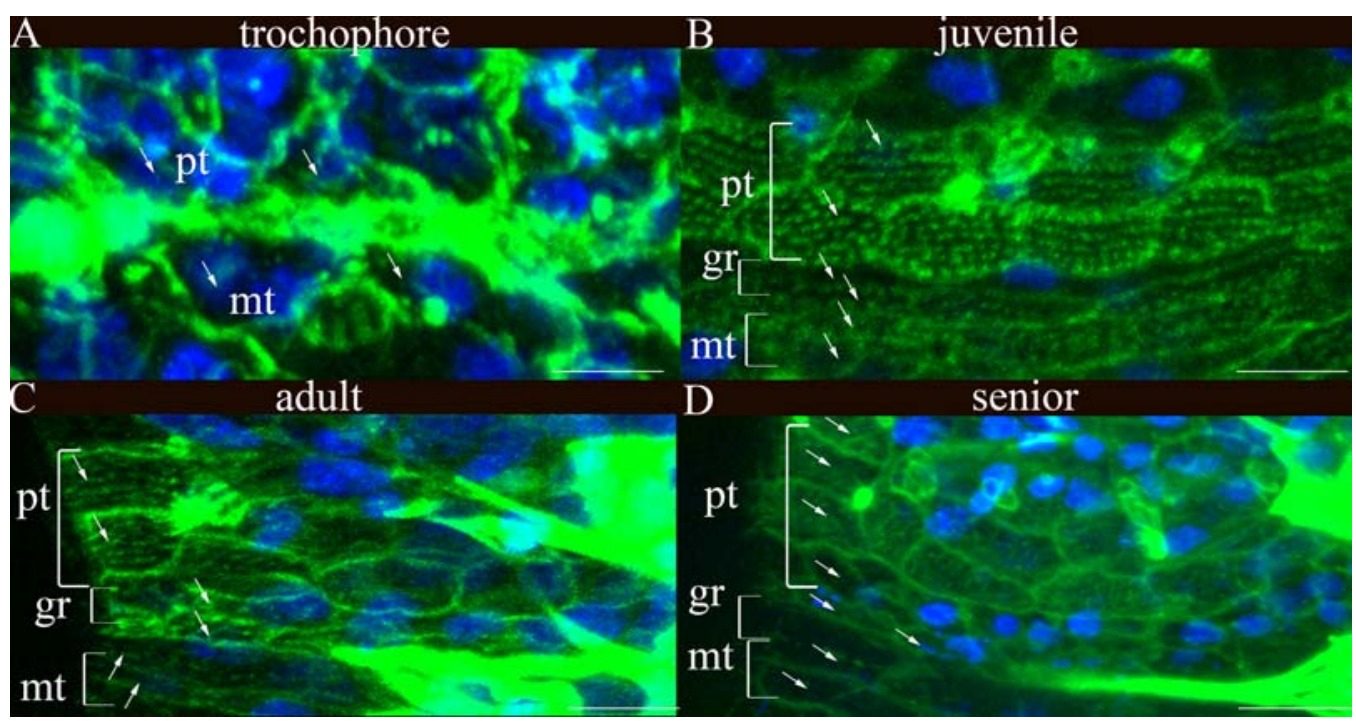

Fig. 7. Morphological changes in the cells of the prototroch, groove, and metatroch of Dimorphilus gyrociliatus, lateral view. A - the trochophore stage, 2 days after oviposition; B — the juvenile stage, 5 days after oviposition; $\mathrm{C}$ - the adult stage, 25 days after oviposition; $\mathrm{D}$ - the senior stage, 75 days after oviposition.

Red - tubulin, green - actin, blue - nuclei. Abbreviations: act — acrotroch; gr — groove; mo - mouth; $\mathrm{mt}$ metatroch; $\mathrm{pt}-$ prototroch, each arrow indicates a band of cell. Scale bars: $\mathrm{A}-5 \mu \mathrm{m}, \mathrm{B}-7 \mu \mathrm{m}, \mathrm{C}-10 \mu \mathrm{m}, \mathrm{D}-$ $10 \mu \mathrm{m}$.

Рис. 7. Морфологические изменения клеток прототроха, желобка и метатроха Dimorphilus gyrociliatus, вид сбоку. А - стадия трохофоры, 2 дня после откладки кокона; В - ювенильная особь, 5 дней после откладки кокона; C - взрослая особь, 25 дней после откладки кокона; D — возрастная особь, 75 дней после откладки кокона.

Красный — тубулин, зеленый — актин, синий - ядра. Обозначения: act — акротрох; gr — желобок; mо — pот; $\mathrm{mt}$ - метатрох; pt - прототрох. Масштабы: A -5 мкм, B - 7 мкм, $\mathrm{C}-10$ мкм, D -10 мкм.

and is used for locomotion. The prototroch of Phyllodoce vulgate was described in highest detail and includes one incomplete ring of ciliary cells, two complete rings of ciliated cells, and accessory cells (Damen, Dictus, 1994; Dictus, Damen, 1997). The most prominent ring consists of 21 multiciliated cells created by primary, secondary, and accessory trochoblasts. In Alitta virens, the prototroch consists of 12 multiciliated cells. Additional anterior (in the episphere) and posterior (in the hyposphere) supporting cells adhere to the main row of cells (Kostyuchenko, Dondua, 2006).

The ciliary structures we described on the ventral and lateral sides of the $D$. gyrociliatus prostomial region fit Nielsen's description of a planktotrophic protostome larva. The anterior ciliated row represents a structure similar to the prototroch, the posterior row represents a structure similar to the metatroch, and the intermediate represents the adoral ciliary zone. Such organization suggests that $D$. gyrociliatus may use the ciliary structures of the prostomial region for filter-feeding, complementing food uptake by bulb scrabbing as the animals get older and larger. Moreover, our experiments support this suggestion (see below).

The structure and relative position of all ciliated structures are very important for planktotrophic filter-feeding free-swimming larvae and less pronounced or absent in lecithotrophic larvae. In planktotrophic trochophores, the anterior and posterior edges of the adoral ciliary zone consist of multiciliated cells arranged in bands, bearing long cilia: prototroch and metatroch, which play an essential role in nutrition. 


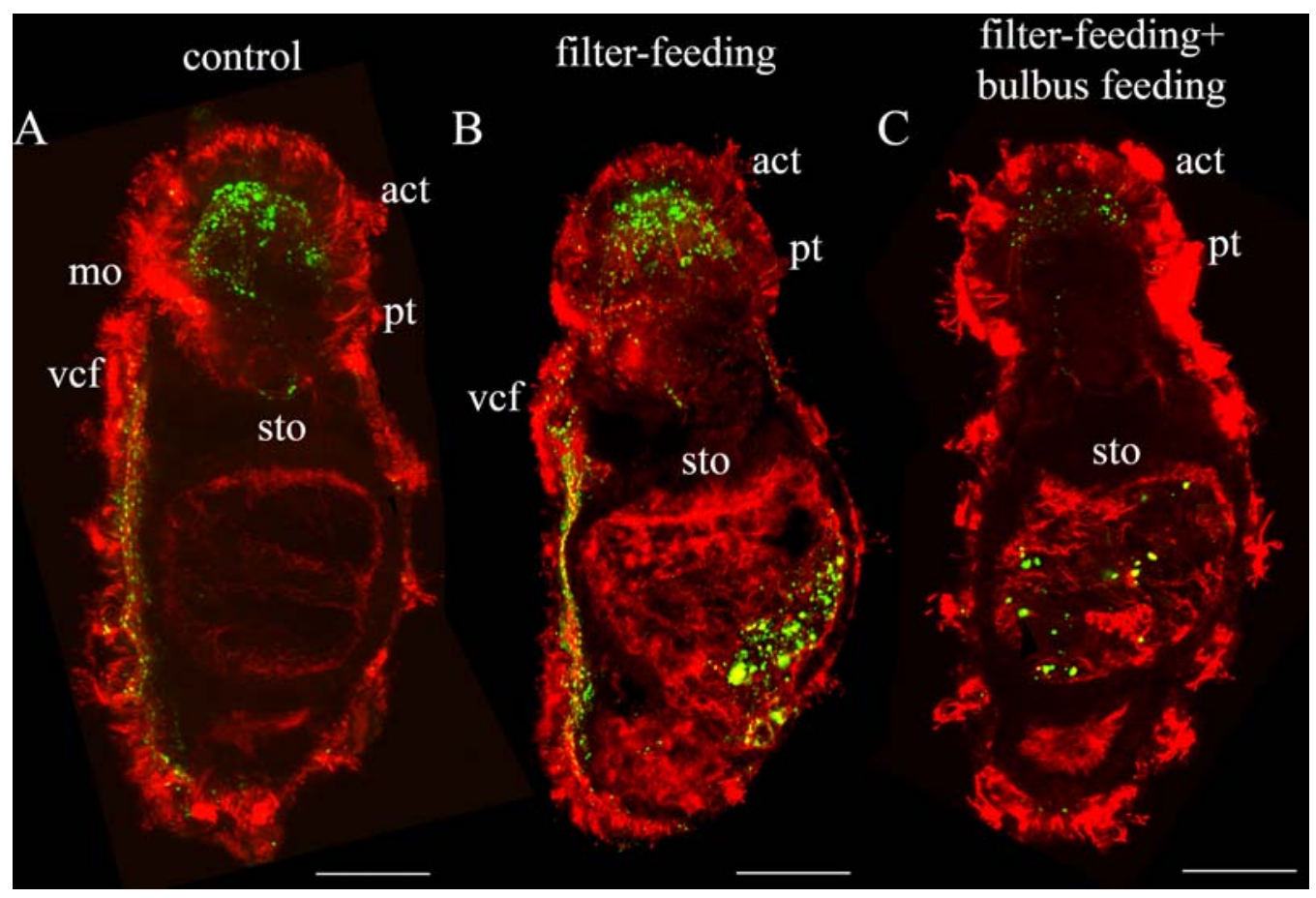

Fig. 8. Feeding experiment on Dimorphilus gyrociliatus juveniles. A — control group, the stomach is empty, with no food particles; B — the first experimental group, magnesium treated, filter-feeding only; $\mathrm{C}$ - the second experimental group, without magnesia, filter-feeding, and bulbus feeding. Food particles (green) only in B and C.

Abbreviations: act — acrotroch; acz — anterior ciliary zone; mo — mouth; sto — stomodeum; pt — prototroch; vcf — ventral ciliary field. Scale bar $30 \mu \mathrm{m}$.

Рис. 8. Эксперимент с питанием ювенильных особей Dimorphilus gyrociliatus сразу после вылупления. A - контрольная группа, кишечник пустой, без пищевых частиц; В - первая экспериментальная группа, в кишечнике есть пищевые частицы; C - вторая экспериментальная группа, в кишечнике есть пищевые частицы.

Обозначения: act — акротрох; acz — передняя ресничная зона; то — рот; sto — кишка; pt — прототрох; vcf — вентральная ресничная полоска. Обозначения: act — акротрох; acz — передняя ресничная зона; то — рот; sto кишка; pt - прототрох; vcf — вентральная ресничная полоска. Масштаб $30 \mu \mathrm{m}$.

In lecithotrophic trochophores, a prototroch of long cilia can rarely be distinguished, and a metatroch is generally absent. All cilia of the adoral ciliary zone are generally of the same length. Furthermore, there is often a ventromedian longitudinal band of cilia corresponding to a ventral ciliary field or gastrotroch or neurotro$\mathrm{ch}$, which is often wide in lecithotrophic larvae.

According to our results, Dimorphilus combines the features of both planktotrophic and lecithotrophic types of larvae. Like planktotrophic larvae, Dimorphilus uses its prototro- ch and metatroch cilia of the prostomial region for feeding; and it uses the ventral ciliary field for gliding locomotion like lecithotrophic animals (Fofanova et al., 2017).

Our morphological results obtained by the modern confocal laser scanning microscopy (CLSM) demonstrate that especially the prostomial ciliary bands have a complex structure. The advantage of CLSM is the possibility of optical slicing of thick structures, thereby maintaining thin focus layers and allowing for a close examination of small morphological details 

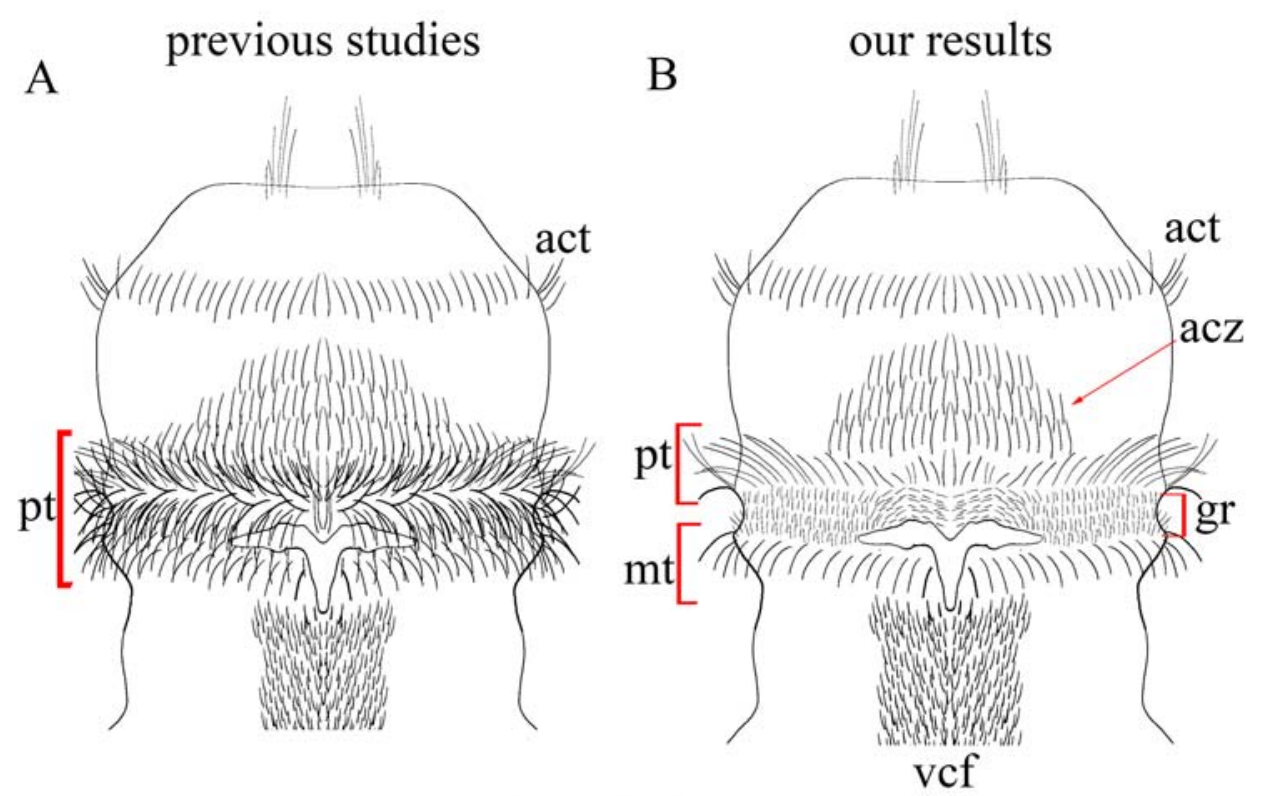

lateral view
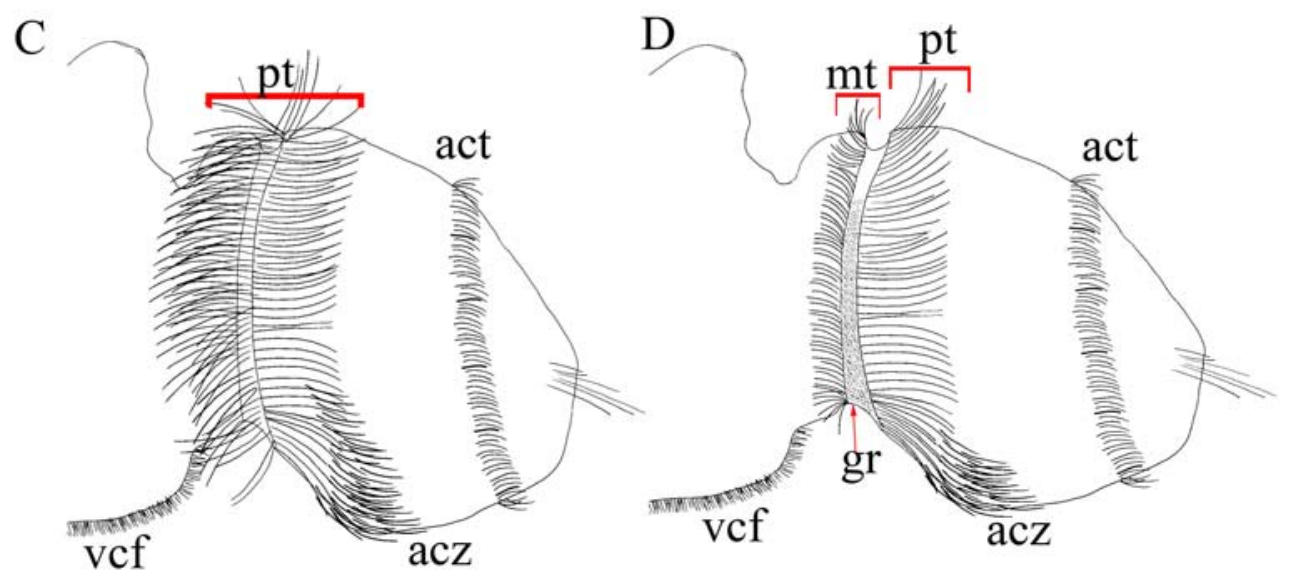

Fig. 9. Schematic representation of Dimorphilus gyrociliatus feeding apparatus comparing previous studies and our results. A, C - massive circular ciliary band (prototroch), diagram based on Kerbl et al., 2016; B, D - our results show prototroch, adoral ciliary zone, and metatroch, representing a downstream filterfeeding apparatus.

Abbreviations: act — acrotroch; acz — anterior ciliary zone; gr — groove; mo — mouth; mt — metatroch; pt — prototroch.

Рис. 9. Схематичное изображение пищедобывающего аппарата Dimorphilus gyrociliatus. A, C мощный прототрох с длинными ресничками, расположенный над ротовым отверстием, на основании данных Kerbl et al., 2016; В, D - наши результаты, показывающие прототрох с длинными ресничками, адоральную ресничную зону и метатрох с короткими ресничками, представляющие downstream механизм.

Обозначения: act — акротрох; acz — передняя ресничная зона; gr — желобок; mo - ротовое отверстие; $\mathrm{mt}$ метатрох; pt - прототрох. 
above and below the body surface, while a scanning microscope only provides a detailed view of the surfaces of structures or animals. Hence, CLSM and the specific labeling of cell membranes, cilia and nuclei allowed us to see the hidden structures in dinophilid larvae. Thus, this approach is very promising for studying the detailed structure of dense ciliary fields.

\section{The ontogeny of the prototroch region}

The prototroch of planktonic larvae derives from precursor cells called "trochoblasts", which are usually organized into rings derived from "primary trochoblasts", the "accessory trochoblasts," and the "secondary trochoblasts" (Damen, Dictus, 1994; Maslakova et al. 2004; Henry et al., 2007; Hiebert, Maslakova, 2015). The study of prototroch formation in Patella embryo demonstrates the prototroch development early in embryogenesis from precursors $\left(1 \mathrm{q}^{2}\right.$ cells), which may be accompanied by prototroch accessory cells $\left(1 \mathrm{q}^{12}\right.$-cells) and secondary prototroch cells (2q-cells) on the blastoporal side (Damen, Dictus, 1994). The prototroch formation in Alitta virens also showed the development from primary trochoblasts precursor cells (Kostyuchenko, Dondua, 2006).

In our study, we did not follow the details of trophoblasts differentiation, since we started our analysis approximately at trochophore-stage. With the prototroch being a highly conserved structure, we suggest that also the developmental pattern of this ciliary structure is conserved.

Nelson did the detailed cell lineage reconstruction, and also pointed out that an incontinuous prototroch occurs quite often. The limits of the first quartette have been determined by two landmarks, the cells $2 \mathrm{a}^{221}$ and $2 \mathrm{c}^{221}$ on the right and left sides respectively, and that chain of small cells which Nelson has identified as the prototroch. These latter extend over the sides, passing just anterior to the cells $2 \mathrm{a}^{221}$ and $2 \mathrm{c}^{221}$, and around the ventral side as a continuous row, but on the dorsal side there is the wide gap so often found in the early stages of the trochophore larva, and due to the same cause, viz., the nonparticipation of the products of $2 \mathrm{~d}$ in the formation of the prototroch (Nelson, 1904). Accord- ing to Nelson, the second prostomial ciliary band should be considered as the prototroch. This suggestion supports our presented results. However, the trochoblasts' development and fate in D. gyrociliatus require further investigation.

In most studied species, the prototroch degenerates in the course of development. Our results demonstrate the presence of all prostomial ciliated structures in adults and even in senior individuals. On the one hand, this indicates the functional significance of ciliary bands for D. gyrociliatus. Moreover, it demonstrates the paedomorphic character of $D$. gyrociliatus. It rather indicates that $D$. gyrocililatus has evolved by paedomorphosis from an ancestor, whose larvae like had a trochophore and maybe were even free-swimming.

\section{Feeding experiments}

Dimorphilus gyrociliatus survives in laboratory culture and is easy to maintain, but its feeding mechanism remained unclear. Jennings and Gender analyzed the feeding patterns by immersing individuals in seawater with $5 \%$ magnesium chloride to eliminate muscular movements while leaving ciliary beating unimpaired. Thus, the paths of water currents could be traced by following the route taken by ink particles or yeast cells stained with dye (Jennings, Gender, 1969). The authors also used histological techniques to analyze the digestive system morphology and the food components. They demonstrated that natural food for D. gyrociliatus includes diatoms and other unicellular algae, protists, bacteria, and detritus. The particle size ranges from 0.5 to $15 \mu \mathrm{m}$ in diameter.

In the experiments, the authors demonstrated that prostomial ciliary bands are incomplete on the dorsal side, and their cilia are 6-7 $\mu \mathrm{m}$ in length. The cilia of bands beat posteriorly and provide a constant stream of water backward over the dorsal and lateral surfaces of the animal. This can supplement the locomotory action of the ventral ciliary field, but the prime function is to create a water flow that brings suspended particles into contact with the prostomial region, and this occurs both when the animal is 
swimming freely or gliding benthically on the substratum (Jennings, Gender, 1969). The suspended particles are brought to the prostomium by the anterior-posterior water current that adheres to the mucus and passes with it laterally. The bands then convey particles downwards on each side of the head region, where they merge with the cilia clothing its ventral surface. The action of these cilia conveys the particles posteriorly to the mouth.

Our experimental results are following this early detailed work. Furthermore, we demonstrate that $D$. gyrociliatus can uptake food using the ciliary apparatus surrounding the Y-shaped mouth. Although we did not follow the water currents using particles like the aforementioned authors, our morphological description of prostomial ciliation supports the hypothesis of downstream feeding in D. gyrociliatus. The prototroch with long cilia beats posteriorly, and short cilia in the groove adhere particles and direct them to the mouth (Fig. 9).

Like Jennings and Gender, we used magnesium chloride to block muscle contractions. The presence of food particles in magnesium-treated animals supports the idea of ciliary feeding in D. gyrociliatus. The presence of food particles in the untreated fed animals indicates both the use of bulbus and cilia for feeding.

Altogether, our morphological and experimental data indicate that $D$. gyrociliatus uses the ciliary apparatus of the prostomial region for particle uptake in addition to bulbus-scrabbing throughout the whole life. The ciliary apparatus, likely a retained prototroch and metatroch, thereby presents yet another structure hinting at the paedomorphic origin of this species.

Acknowledgements. The research was done using the equipment of the Core Centrum of the Institute of Developmental Biology RAS. Light microscopic studies were conducted using the Center of Microscopy WSBS MSU equipment. The reported study was funded by RFBR, project number 19-34-60040. The work was conducted in the frame of IDB RAS Government Research program \# 0088-2021-0020. We thank Gribova Varvara for the professional language proof- reading. We thank the anonymous reviewers whose comments/suggestions helped improve and clarify this manuscript.

\section{References}

Abramoff M.D. 2004. Image Processing with ImageJ // Bioph. Int. Vol.11. P.36-41.

Amiel A.R., Henry J.Q., Seaver E.C. 2013. An organizing activity is required for head patterning and cell fate specification in the polychaete annelid Capitella teleta: New insights into cell-cell signaling in Lophotrochozoa// Dev. Biol. Vol.379. P.107-122. doi:10.1016/ j.ydbio.2013.04.011.

Damen P., Dictus W.J.A.G. 1994. Cell-lineage analysis of the prototroch of the gastropod mollusc Patella vulgate shows conditional specification of some trochoblasts // Rouxs. Arch. Dev. Biol. Vol.203. P.187-198. doi:10.1007/BF00636334.

Dictus W.J., Damen P. 1997. Cell-lineage and clonalcontribution map of the trochophore larva of Patella vulgata (mollusca) // Mech. Dev. Vol.62. P.213-226. doi:10.1016/S0925-4773(97)00666-7.

Fofanova E., Voronezhskaya E. 2012. The structure of Archiannelid Dinophilus gyrociliatus ventral nerve cords // Acta Biol. Hung. Vol.63. P.88-90. doi:10.1556/ABiol.63.2012.Suppl.2.11.

Fofanova E.G., Mayorova T.D., Voronezhskaya E.E. 2017. Paradoxical effect of serotonin on ciliary locomotion of the adult archiannelid worms Dinophilus gyrociliatus and D. taeniatus (Annelida: Polychaeta) // Invert. Zool. Vol.14. P.114-120. doi:10.15298/invertzool.14.2.03.

Fofanova E.G., Nezlin L.P., Voronezhskaya E.E. 2014. Ciliary and nervous structures in juvenile females of the annelid Dinophilus gyrociliatus (O. Schmidt, 1848) (Annelida: Polychaeta) // Rus. J. Mar. Biol. Vol.40. P.43-52. doi:10.1134/S1063074014010040.

Graff L. 1882. Monographie der Turbellarien. I. Rhabdocoelida. Leipzig: W. Engelmann. 454 S.

Hatschek B. 1878. Studien über Entwicklungsgeschichte der Anneliden. Ein Beitrag zur Morphologie der Bilaterien // Arb. Zool. Inst. Univ. Wien. Bd.1. S.277-404.

Henry J.Q., Hejnol A., Perry K.J., Martindale M.Q. 2007. Homology of ciliary bands in Spiralian Trochophores // Integ. Comp. Biol. Vol.47. P.865-871. doi:10.1093/ icb/icm035.

Hermans C.O. 1969. The Systematic Position of the Archiannelida // Syst. Zool. Vol.18. P.85-102. doi:10. 2307/2412412.

Hiebert L.S., Maslakova S.A. 2015. Expression of Hox, $\mathrm{Cdx}$, and Six $3 / 6$ genes in the hoplonemertean Pantinonemertes californiensis offers insight into the evolution of maximally indirect development in the phylum Nemertea // Evodevo. Vol.6. P.26. doi:10.1186/ s13227-015-0021-7.

Ivanova-Kazas O.M. 1995. [Evolutionary Embryology of Animals]. St. Petersbourg: Nauka. 565 p. [In Russian] 
Jennings J.B., Gelder S.R. 1969. Feeding and digestion in Dinophilus gyrociliatus (Annelida: Archiannelida) // J. Zool. Vol.158. P.441-451. doi:10.1111/j.14697998.1969.tb02161.x.

Jimi N., Minokawa T., Miura T., Kajihara H. 2020. Meiobenthic polychaete Dinophilus sp. cf. gyrociliatus (Annelida: Dinophilidae) from Japan with SEM Observation and DNA Barcodes // Spec. Div. Vol.25. P.213-218. doi:10.12782/specdiv.25.213.

Jones E.R., Ferguson F.F. 1957. The genus Dinophilus (Archiannelida) in the United States // Amer. Midland Natur. Vol.57. P.440-449. doi:10.2307/2422409.

Kerbl A., Conzelmann M., Jékely G., Worsaae K. 2017. High diversity in neuropeptide immunoreactivity patterns among three closely related species of Dinophilidae (Annelida) // J. Comp.Neurol. Vol.525. P.35963635. doi:10.1002/cne.24289.

Kerbl A., Fofanova E.G., Mayorova T.D., Voronezhskaya E.E., Worsaae K. 2016. Comparison of neuromuscular development in two dinophilid species (Annelida) suggests progenetic origin of Dinophilus gyrociliatus // Front. Zool. Vol.13. P.49. doi:10.1186/s12983016-0181-x.

Kleinenberg N. 1886. Die Entstehung des Annelides aus der Larve von Lopadorhynchus // Zeit. Wiss. Zool. Bd.44. S.1-227.

Kostyuchenko R.P., Dondua A.K. 2006. Development of the prototroch in embryogenesis of Nereis virens (polychaeta) // Rus. J. Dev. Biol. Vol.37. P.69-76. doi:10.1134/S1062360406020020.

Lacalli T.C. 1986. Prototroch structure and innervation in the trochophore larva of Phyllodoce (Polychaeta) // Can. J. Zool. Vol.64. P.176-184. doi:10.1139/z86-028.

Lacalli T.C. 1988. The larval reticulum in Phyllodoce (Polychaeta, Phyllodocida) // Zoomorphol. Vol.108. P.61-68. doi:10.1007/BF00312215.

Lang A. 1884. Die Polycladen (Seeplanarien) des Ggolfes von Neapel und der angrenzenden Meeres-Abschnitte. Leipzig: W. Engelmann. 29 S. doi:10.5962/bhl. title. 10545 .

Marinković M., Berger J., Jékely G. 2020. Neuronal coordination of motile cilia in locomotion and feeding // Phil. Trans. R. Soc. B. Vol.375. P.20190165. doi:10. 1098/rstb.2019.0165.

Martín-Durán J.M., Vellutini B.C., Marlétaz F., Cetrangolo V., Cvetesic N., Thiel D., Henriet S., Grau-Bové X., Carrillo-Baltodano A.M., Gu W., Kerbl A., Marquez Y., Bekkouche N., Chourrout D., Gómez-Skarmeta J.L., Irimia M., Lenhard B., Worsaae K., Hejnol A. 2021. Conservative route to genome compaction in a miniature annelid // Nat. Ecol. Evol. Vol.5. P.231242. doi:10.1038/s41559-020-01327-6.

Maslakova S.A., Martindale M.Q., Norenburg J.L. 2004. Vestigial prototroch in a basal nemertean, Carinoma tremaphoros (Nemertea; Palaeonemertea)//Evol. Dev. Vol.6. P.219-226. doi:10.1111/j.1525-142X.2004. 04027.x.

Mauri M., Simonini R., Baraldi E. 2002. Demographic responses of the polychaete Dinophilus gyrociliatus to chromium exposure // Environ. Toxicol. Chem.
Vol.21. P.1903-1907. doi:10.1002/etc.5620210918. Müller M.C.M. 2006. Polychaete nervous systems: ground pattern and variations-cLS microscopy and the importance of novel characteristics in phylogenetic analysis // Integr. Comp. Biol. Vol.46. P.125-133. doi:10.1093/ $\mathrm{icb} / \mathrm{icj} 017$.

Nelson J.A. 1904. The Early Development of Dinophilus: A Study in Cell-Lineage // Proc. Acad. Nat. Sci. Phil. Vol.56. P.687-737.

Nelson J.A. 1907. The Morphology of Dinophilus Conklini n. sp // Proc. Acad. Nat. Sci. Phil. Vol.59. P.82-143.

Nielsen C. 2004. Trochophora larvae: Cell-lineages, ciliary bands, and body regions. 1 . Annelida and Mollusca // J. Exp. Zool. Vol.302B. P.35-68. doi:10.1002/ jez.b.20001.

Nielsen C. 2009. How did indirect development with planktotrophic larvae evolve? // Biol. Bull. Vol.216. P.203-215. doi:10.1086/BBLv216n3p203.

Riisgård H.U., Larsen P.S. 2001. Minireview: ciliary filter feeding and bio-fluid mechanics-present understanding and unsolved problems // Limnol. Oceanogr. Vol.46. P.882-891. doi:10.4319/1o.2001.46.4.0882.

Rouse G.W. 1999. Trochophore concepts: ciliary bands and the evolution of larvae in spiralian Metazoa // Biol. J. Linn. Soc. Vol.66. P.411-464. doi:10.1111/ j.1095-8312.1999.tb01920.x.

Rouse G.W. 2000. Bias? What bias? The evolution of downstream larval-feeding in animals // Zool. Scripta. Vol.29. P.213-236. doi:10.1046/j.1463-6409.2000. 00040.x.

Schimkewitsch W. 1895. Zur Kenntnis des Baues und der Entwicklung des Dinophilus vom Weifsen Meere // Zeits. für wiss. Zool. Bd.59. S.46-79.

Schmidt O. 1857. Zur Kenntnis der Turbellaria, Rhabdocoela und einiger anderer Würmer des Mittelmeeres // Sitz. Kais. Akad. Wiss. W. Math. Nat. K1. Bd.23. S.347-366.

Shearer C. 1911. The problem of sex determination in Dinophilus gyrociliatus // J. Mar. Biol. As. UK. Vol.9. P.156-160. doi:10.1017/S002531540007332X.

Windoffer R., Westheide W. 1988a. The nervous system of the male Dinophilus gyrociliatus (Polychaeta, Dinophilidae): I. Number, types and distribution pattern of sensory cells // Act. Zool. Vol.69. P.55-64. doi:10.1111/j.1463-6395.1988.tb00901.x.

Windoffer R., Westheide W. 1988b. The nervous system of the male Dinophilus gyrociliatus (Polychaeta, Dinophilidae): II. Electron microscopical reconstruction of nervous anatomy and effector cells // J. Comp. Neurol. Vol.272. P.475-488. doi:10.1002/cne. 902720403.

Wu L., Hiebert L.S., Klann M., Passamaneck Y., Bastin B.R., Schneider S.Q., Martindale M.Q., Seaver E.C., Maslakova S.A., Lambert J.D. 2020. Genes with spiralian-specific protein motifs are expressed in spiralian ciliary bands // Nat. Com. Vol.11. P.4171. doi:10. 1038/s41467-020-17780-7.

Responsible editors R.P. Kostyuchenko, E.N Temereva 